\title{
TITLE:
}

\section{COMPOSITION OF THE FIXED SEA URCHIN COLONY ON HATAKEZIMA ISLAND, 1972-1974}

$\operatorname{AUTHOR(S):~}$

Yanagisawa, Yasunobu

\section{CITATION:}

Yanagisawa, Yasunobu. COMPOSITION OF THE FIXED SEA URCHIN COLONY ON HATAKEZIMA ISLAND, 1972-1974. PUBLICATIONS OF THE SETO MARINE BIOLOGICAL LABORATORY 1974, 21(5-6): 409-410

\section{ISSUE DATE:}

1974-12-23

URL:

http://hdl.handle.net/2433/175872

RIGHT: 


\section{COMPOSITION OF THE FIXED SEA URCHIN COLONY ON HATAKEZIMA ISLAND, 1972-1974}

The examinations were made on July 10,1972 (the water was lowest, $2 \mathrm{~cm}$, at $11: 28$; it was cloudy; the sea was calm), on July 2, 1973 (the water lowest, $-5 \mathrm{~cm}$, at $13: 08$; fine; breeze from west ; the sea calm) and on June 20,1974 (the water lowest, $-1 \mathrm{~cm}$, at $11: 55$; fine ; wind from SSW, but waves insignificant), respectively.

Table 1. Population composition in the fixed echinid colony in 1972-1974.

\begin{tabular}{l||c|c|c|c||r|r}
\multicolumn{1}{c|}{ 1972, July 10 } & $\begin{array}{c}\text { Section 1 } \\
\text { (SW) }\end{array}$ & $\begin{array}{c}\text { Section 2 } \\
\text { (NW) }\end{array}$ & $\begin{array}{c}\text { Section 3 } \\
\text { (SE) }\end{array}$ & $\begin{array}{c}\text { Section 4 } \\
\text { (NE) }\end{array}$ & Total & Percent \\
\hline Anthocidaris crassispina & 60 & 89 & 54 & 69 & 272 & 33.1 \\
Echinostrephus aciculatus & 60 & 217 & 87 & 100 & 464 & 56.5 \\
Echinometra mathaei & 6 & 23 & 24 & 31 & 84 & 10.3 \\
Mespilia globulus & & & & 1 & 1 & 0.1 \\
\hline
\end{tabular}

\begin{tabular}{|c|c|c|c|c|c|c|}
\hline 1973 , July 2 & $\begin{array}{l}\text { Section } 1 \\
(\mathrm{SW})\end{array}$ & $\begin{array}{l}\text { Section } 2 \\
(\mathrm{NW})\end{array}$ & $\begin{array}{l}\text { Section } 3 \\
\quad(\mathrm{SE})\end{array}$ & $\begin{array}{l}\text { Section } 4 \\
\quad(N E)\end{array}$ & Total & Percent \\
\hline Anthocidaris crassispina & 46 & 67 & 58 & 67 & 238 & 29.9 \\
\hline Echinostrephus aciculatus & 56 & 215 & 98 & 102 & 471 & 59.3 \\
\hline Echinometra mathaei & 8 & 22 & 26 & 28 & 84 & 10.6 \\
\hline Mespilia globulus & & 1 & & & 1 & 0.1 \\
\hline $\begin{array}{l}\text { Hemicentrotus } \\
\qquad \text { pulcherrimus }\end{array}$ & & 1 & & & 1 & 0.1 \\
\hline & & & & & 795 & 100.0 \\
\hline
\end{tabular}

\begin{tabular}{l||c|c|c|c|c|c|}
\hline \multicolumn{1}{c|}{ 1974, June 20 } & $\begin{array}{c}\text { Section 1 } \\
\text { (SW) }\end{array}$ & $\begin{array}{c}\text { Section 2 } \\
\text { (NW) }\end{array}$ & $\begin{array}{c}\text { Section 3 } \\
\text { (SE) }\end{array}$ & $\begin{array}{c}\text { Section 4 } \\
\text { (NE) }\end{array}$ & Total & Percent \\
\hline Anthocidaris crassispina & 49 & 65 & 67 & 62 & 243 & 30.1 \\
Echinostrephus aciculatus & 61 & 207 & 94 & 110 & 472 & 58.4 \\
Echinometra mathaei & 6 & 25 & 25 & 37 & 93 & 11.5 \\
\hline
\end{tabular}

The ratio of Echinostrephus to Anthocidaris (E/A) in the three years is given in Table 2. The ratio has been much raised in these years and this is seemingly brought about evidently by a considerable increase of Echinostrephus. The density of Echinometra in the area has steadily Publ. Seto Mar. Biol. Lab., XXI, 409-410, 1974. (Biological data 1) 
increased for the last decade. The definite decrease of Mespilia in these years is to be noted, as this might reflect the sea-water pollution around Hatakezima Island.

Table 2. The ratio of Echinostrephus to Anthocidaris. (E/A) in 1972-1974.

\begin{tabular}{|c|c|c|c|}
\hline & 1972 & 1973 & 1974 \\
\hline $\mathrm{E} / \mathrm{A}$ & 1.706 & 1.983 & 1.950 \\
\hline
\end{tabular}

A noteworthy event of the sea urchin fauna in the three years must be the outbreak of Temnopleurus (Toreumatica) reevesi (Gray) in the shallow waters near the laboratory. This sea urchin is distributed widely in the coastal waters of Japan deeper than $5 \mathrm{~m}$, but never abundantly. In Tanabe Bay, a small number of this sea urchin has actually been found in catches of commercial trawling. However, it had never been found in shallows less than $5 \mathrm{~m}$ near the laboratory before the spring season of 1973.

On May 30 and June 3, 1973, tremendous numbers of this sea urchin were stranded on the northern beach of the laboratory ground and similar stranding in a slightly smaller scale on July 14 . Small numbers of juvenile urchins of Pseudocentrotus depressus (A. Agassiz) and Hericentrotus pulcherrimus (A Agassiz) were found mingled with Temnopleurus. Observations by diving revealed that Temnopleurus was distributed densely within $200 \mathrm{~m}$ from the shore in $1-7 \mathrm{~m}$ deep shallows below the northern beach, the density attaining 70 urchins $/ 10 \mathrm{~m}^{2}$ or more in the ranges $120-140 \mathrm{~m}$ and $190-200 \mathrm{~m}$ from the shore. A significant number, though not so many but unusual in this area, of Echinocardium cordatum (Pennant) were found in swarms of Temnopleurus. Similarly dense swarms of this sea urchin were confirmed in a limited area at the tip of the cape, the neck part of which is occupied by the laboratory and the area is far separated from the northern beach of the laboratory by rocky areas. No swarms were observed in any other parts of the vicinity. And an observation on October 6 showed that all those swarms had completely disappeared already. Probably the appearance of abundant Temnopleurus in shallows near the laboratory was brought about by spawning migration of this sea urchin in the summer season; actually some spents were included in stranded urchins. Further, this outbreak in the above-mentioned areas might be caused by unusually successful falling of unusually dense imagoes of this sea urchin, being accompanied with those of Echinocardium. Lastly, it is somewhat allusive that Lovenia elongata (Gray) was observed unusually frequently by members of the laboratory aquarium in sandy shallows below the southern beach of Hatakezima Island in summer of 1972 .

The regular observation in 1972 on Hatakezima Island was made in collaboration with Mr. Hiroshi Kawahara, while the observations on Temnopleurus were done in cooperation with Mr. Hidetomo Tanase. For the details of the latter, refer to an article in Nanki Seibutu, 15 (2), 1973, pp. $37-40$ (in Japanese). 